УДК 579

DOI: $10.33184 /$ spbgb-2021-09-21.42

\title{
Метагеномный анализ структуры прокариотных сообществ горизонтов почв при No-Till технологии
}

\author{
() 3.Ю. Сираева*, Е.А. Булыгина, Р.К. Исмагилова, О.А. Кравцова \\ ФГАОУ ВО «Казанский (Приволжский) фредеральный университет» \\ Россия, Республика Татарстан, 420008, г. Казань, ул. Кремлевская, 18 \\ *Email: zsiraeva@yandex.ru
}

Впервые в Республике Татарстан с помощью микробиологического и метагеномного анализа изучена структура прокариотных сообществ горизонтов почв при No-Till технологии.

Ключевые слова: №-Till технология, метагеномный анализ, микробиом, структура прокариотных сообществ почв.

На данный момент уровень плодородия почв во многом отличается от прошлых лет [1]. Сельскохозяйственные угодья, предназначенные для выращивания различных культур, подвергаются химическому воздействию в виде обработки пестицидами и внесения минеральных удобрений [2], что оказывает токсическое действие на бактериальное сообщество, являющееся основой биологической активности и, как следствие, плодородия почвы [3]. В связи с этим внимание многих исследователей и агропроизводителей обращено к No-Till технологии, известной как система нулевой обработки почвы, при которой механическому воздействию подвергается только поверхностный слой на уровне глубины посева [4].

Изучение бактериального сообщества почвы позволяет судить о биологическом разнообразии, плодородии почвы и сельскохозяйственной пригодности. Традиционным методом оценки относительного обилия таксонов является классический метод посева на питательные среды [5]. Однако методы микробиологии позволяют выявить лишь малую часть (от 1,5 до 5,0\%) представителей бактериального сообщества [6]. Полно охарактеризовать прокариотное сообщество почвы возможно с помощью метагеномного анализа $[6,7]$.

В литературе имеются единичные данные о структуре микробного сообщества почвы, культивируемой по No-Till технологии [8]. Цель исследования - сравнительный микробиологический и метагеномный анализ прокариотных сообществ почвенных горизонтов при No-Till технологии.

В работе исследовали поле ООО «Тойма» Кукморского района Республики Татарстан, культивируемого по No-Till технологии с 2011 года. Типы почв: серая лесная глинистая (равнинный ландшафт), серая лесная тяжелосуглинистая (склон). Предшественник горох посевной (Pisum sativum L.), сорт Усатый кормовой. Посевная культура - ячмень яровой (Hordeum vulgare L.), сорт НУР, PC-2. Образцы почвы отбирали после посева (25.05.2019) по [9] по генетическим горизонтам профиля из разреза глубиной 100 см.

Влажность почвы определяли согласно [10], $\mathrm{pH}$ солевой вытяжки - по [11], содержание гумуса - по [12], азота - по [13], подвижного фросфрора и калия - по [14]. 
Для качественной оценки структуры прокариотного сообщества и учета представителей эколого-трофических групп микроорганизмов использовали метод посева серийных разведений на селективные среды [15] и метод почвенных комочков [16]. Родовую и видовую принадлежность бактерий определяли по [17-19].

Выделение ДНК из образцов проводили по стандартному протоколу [20]. Подготовку геномной библиотеки осуществляли согласно протоколу 16S Metagenomic Sequencing Library Preparation Protocol (llumina MiSeq). Качественную проверку библиотек производили на чипе Bioanalyzer DNA 1000 Chip, концентрацию амликонов измеряли на прибоpe Qubit 2.0 Fluorometer (Invitrogen, США) с использованием Quant-iт ${ }^{\mathrm{TM}}$ dsDNA HighSensitivity Assay Kit (Thermo Fisher, США). Секвенирование образцов проводили на приборе MiSeq (Illumina, США) согласно протоколу. Данные секвенирования анализировали с помощью программного обеспечения QIIME pipeline версия 1.9.1 [21], статистический анализ метагеномных данных - с помощью программы RStudio.

Известно, что структура прокариотного сообщества почвы определяется рядом факторов. В связи с этим построена картограмма поля, отображающая особенности рельефа (рисунок 1), проведен диффреренциальный отбор образцов (рисунок 2) и агрохимический анализ (таблица 1).

Как видно из картограммы (рисунок 1), поле характеризуется рельефом смешанного типа: меньшая часть поля (23 га) - склоновая; бо́льшая (97 га) представляет собой равнинный возвышенный ландшафт.

Выявлены различия в агрохимическом фоне в зависимости от ландшафта: почва поля на склоновой части более кислая с пониженным содержанием подвижного фросфора и калия, но с более высоким содержанием азота и гумуса (таблица 1).

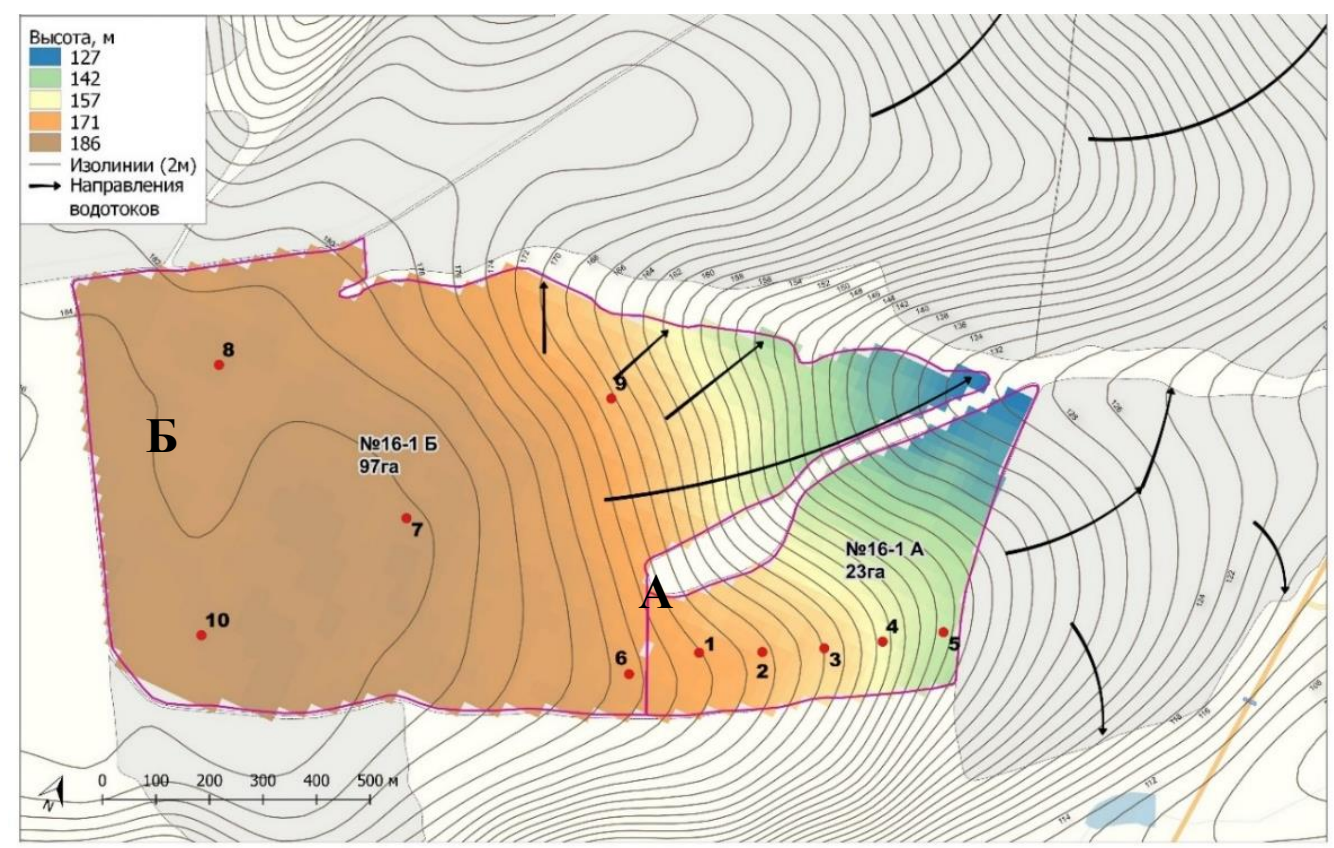

Рис. 1. Картограмма поля Кукморского района Республики Татарстан (А - склон; Б равнинный возвышенный ландшафт). 


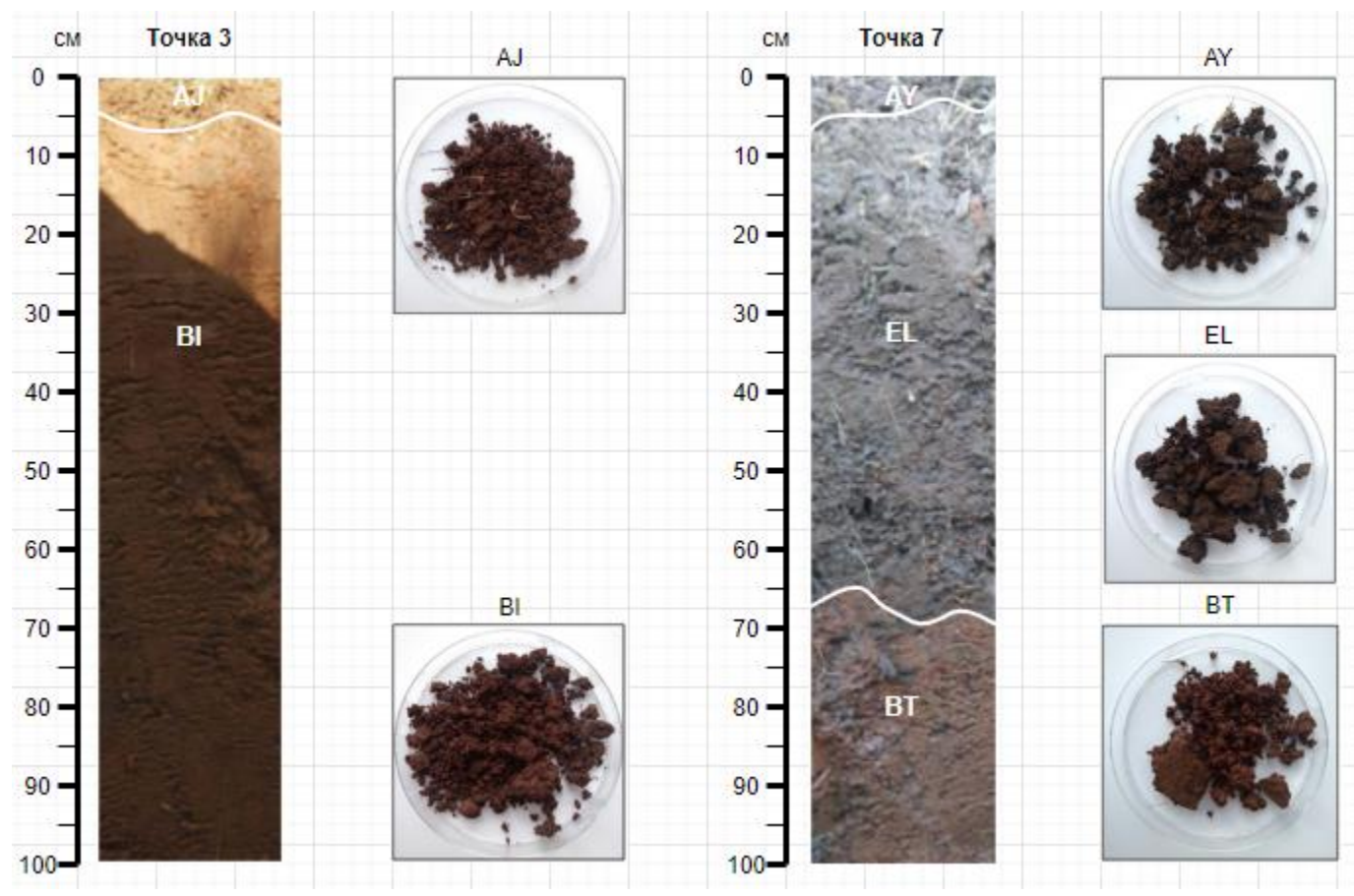

Рис. 2. Горизонты почв в точках 3 (AJ-BI) и 7 (AY-EL-BT).

Таблица 1. Агрохимические показатели почвы.

\begin{tabular}{|l|c|c|}
\hline \multirow{2}{*}{ Показатель } & \multicolumn{2}{|c|}{ Ландшафт } \\
\cline { 2 - 3 } & Точка 3 (склон) & Точка 7 (равнинный ландшафт) \\
\hline $\mathrm{pH}$ & $5,9 \pm 0,24$ & $6,8 \pm 0,39$ \\
\hline Подвижный фоссрор, мг/кг & $150,0 \pm 11$ & $199,0 \pm 13$ \\
\hline Подвижный калий, мг/кг & $122,0 \pm 10$ & $174,0 \pm 9$ \\
\hline Органическое вещество, \% & $4,1 \pm 0,29$ & $3,2 \pm 0,11$ \\
\hline щелочногидролизуемый азот, мг/кг & $101,0 \pm 8$ & $81,0 \pm 6$ \\
\hline
\end{tabular}

Традиционным методом оценки относительного обилия таксонов является классический метод посева на питательные среды. В то же время в качестве диагностического показателя почвенного плодородия рассматривают баланс в почве определенных физиологических групп микроорганизмов $[1,5]$. Для оценки уровня плодородия почвы проведен анализ родового состава (таблица 2) и численности эколого-трофических групп микроорганизмов (таблица 3).

Таксономический состав почвенных образцов характеризуется бо́льшей представленностью типично сапротрофной почвенной микрофлоры из рода Bacillus и филума Actinobacteria (таблица 2). Численность аммонификаторов и бактерий, использующих минеральные формы азота, высокая - в диапазоне от $(1,1 \pm 0,09) \times 10^{5}$ до $(3,9 \pm 0,12) \times 10^{6}$ КОЕ/г абс. сух. почвы. С большей долей вероятности эти группы, вовлеченные в азот- 
ный круговорот, представлены бактериями из родов Bacillus и Pseudomonas (таблица 2), способные выполнять функцию как аммонификаторов, так и нитрификаторов. Бактерии рода Micrococcus, численность которых снижалась по горизонтам, за исключением горизонта EL в точке 7 (таблица 2), являются деструкторами, разлагающими преимущественно безазотистое органическое вещество [5]. Вероятно, основной вклад в разложение органических остатков вносят представители рода Micrococcus, что коррелирует с постепенным снижением целлюлозоразрушающих бактерий по всему профилю (таблица 3).

Таблица 2. Родовой состав бактериального сообщества.

\begin{tabular}{|c|c|c|c|c|c|}
\hline \multirow{3}{*}{ Род бактерий } & \multicolumn{5}{|c|}{ Численность микроорганизмов, (M \pm m) КОЕ/г асб. сух. почвы } \\
\hline & \multicolumn{2}{|c|}{ точка 3 (склон) } & \multicolumn{3}{|c|}{ точка 7 (равнинный ландшафрт) } \\
\hline & горизонт AJ & горизонт ВІ & горизонт AY & горизонт EL & горизонт ВТ \\
\hline Bacillus & $(1,3 \pm 0,07) \times 10^{5}$ & $(0,9 \pm 0,07) \times 10^{5}$ & $(2,6 \pm 0,19) \times 10^{5}$ & $(3,8 \pm 0,24) \times 10^{4}$ & $(6,3 \pm 0,23) \times 10^{4}$ \\
\hline Pseudomonas & $(1,8 \pm 0,04) \times 10^{3}$ & $(6,5 \pm 0,27) \times 10^{3}$ & $(5,3 \pm 0,27) \times 10^{3}$ & $(5,3 \pm 0,27) \times 10^{3}$ & $(2,3 \pm 0,22) \times 10^{3}$ \\
\hline Flavobacterium & $(2,4 \pm 0,04) \times 10^{3}$ & $(1,9 \pm 0,13) \times 10^{3}$ & $(1,8 \pm 0,11) \times 10^{2}$ & $(2,8 \pm 0,16) \times 10^{2}$ & $(1,9 \pm 0,17) \times 10^{2}$ \\
\hline $\begin{array}{l}\text { poda фрилума Ac- } \\
\text { tinobacteria }\end{array}$ & $(9,2 \pm 0,14) \times 10^{4}$ & $(2,2 \pm 0,11) \times 10^{6}$ & $(3,3 \pm 0,17) \times 10^{5}$ & $(3,8 \pm 0,11) \times 10^{6}$ & $(4,7 \pm 0,12) \times 10^{4}$ \\
\hline $\begin{array}{l}\text { в том числе, Mi- } \\
\text { сrососсиs }\end{array}$ & $(3,1 \pm 0,02) \times 10^{4}$ & $(4,3 \pm 0,31) \times 10^{3}$ & $(1,2 \pm 0,09) \times 10^{4}$ & $(1,2 \pm 0,09) \times 10^{5}$ & $(1,0 \pm 0,1) \times 10^{3}$ \\
\hline $\begin{array}{l}\text { Неидентифи- } \\
\text { цированные }\end{array}$ & $(8,0 \pm 0,11) \times 10^{5}$ & $(0,9 \pm 0,11) \times 10^{5}$ & $(3,2 \pm 0,22) \times 10^{5}$ & $(1,4 \pm 0,19) \times 10^{5}$ & $(1,4 \pm 0,15) \times 10^{5}$ \\
\hline
\end{tabular}

Примечание: $\mathrm{M} \pm \mathrm{m}$ - среднее значение \pm стандартная ошибка среднего.

Таблица 3. Численность эколого-трофических групп микроорганизмов.

\begin{tabular}{|c|c|c|c|c|c|}
\hline \multirow{3}{*}{$\begin{array}{c}\text { Эколого- } \\
\text { трофрическая } \\
\text { группа }\end{array}$} & \multicolumn{5}{|c|}{ Численность микроорганизмов, (M \pm m) КОЕ/г абс. сух. почвы } \\
\hline & \multicolumn{2}{|c|}{ точка 3 (склон) } & \multicolumn{3}{|c|}{ точка 7 (равнинный ландшафрт) } \\
\hline & горизонт AJ & горизонт ВІ & горизонт AY & горизонт EL & горизонт ВТ \\
\hline $\begin{array}{l}\text { Аммонифицирую- } \\
\text { щие }\end{array}$ & $(1,1 \pm 0,09) \times 10^{5}$ & $(3,9 \pm 0,12) \times 10^{6}$ & $(9,7 \pm 0,20) \times 10^{4}$ & $(4,8 \pm 0,21) \times 10^{5}$ & $(3,2 \pm 0,19) \times 10^{5}$ \\
\hline $\begin{array}{l}\text { Денитрифрициру- } \\
\text { ющие }\end{array}$ & $(2,7 \pm 0,06) \times 10^{4}$ & $(6,7 \pm 0,23) \times 10^{3}$ & $(1,0 \pm 0,09) \times 10^{4}$ & $(2,8 \pm 0,12) \times 10^{4}$ & $(4,0 \pm 0,09) \times 10^{2}$ \\
\hline $\begin{array}{l}\text { Использующие } \\
\text { минеральные } \\
\text { формы азота }\end{array}$ & $(8,9 \pm 0,02) \times 10^{5}$ & $(4,1 \pm 0,27) \times 10^{5}$ & $(1,0 \pm 0,05) \times 10^{6}$ & $(4,7 \pm 0,16) \times 10^{6}$ & $(1,0 \pm 0,08) \times 10^{4}$ \\
\hline
\end{tabular}




\begin{tabular}{|l|c|c|c|c|c|}
\hline $\begin{array}{l}\text { Аэробные азот- } \\
\text { фиксирующие }\end{array}$ & $(2,8 \pm 0,12) \times 10^{2}$ & $(2,1 \pm 0,12) \times 10^{3}$ & $(1,2 \pm 0,04) \times 10^{2}$ & $(1,6 \pm 0,18) \times 10^{3}$ & $(1,1 \pm 0,16) \times 10^{3}$ \\
\hline $\begin{array}{l}\text { Фосфратраство- } \\
\text { ряющие }\end{array}$ & $(5,4 \pm 0,07) \times 10^{3}$ & $(3,5 \pm 0,07) \times 10^{3}$ & $(2,2 \pm 0,10) \times 10^{2}$ & $(1,0 \pm 0,10) \times 10^{2}$ & $(1,1 \pm 0,07) \times 10^{2}$ \\
\hline $\begin{array}{l}\text { Целлюлозоразру- } \\
\text { шающие, \% }\end{array}$ & $52 \pm 4,0$ & $21 \pm 1,4$ & $48 \pm 1,9$ & $29 \pm 1,4$ & $17 \pm 0,6$ \\
\hline Azotobacter, \% & $13 \pm 1,1$ & $22 \pm 1,2$ & $29 \pm 1,7$ & $32 \pm 1,4$ & $8 \pm 0,5$ \\
\hline
\end{tabular}

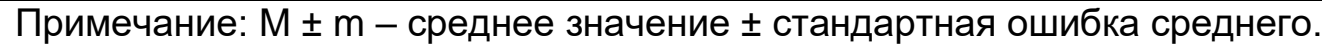

Численность актинобактерий варьировала от $4,7 \pm 0,12 \times 10^{4}$ до $3,8 \pm 0,11 \times 10^{6} \mathrm{KOE} / г$ абс. сух. почвы (таблица 2). Выявленное превышение содержания актинобактерий в равнинной части поля над склоновой (таблица 2) обусловлены, вероятно, оптимальной для актинобактерий (нейтральной) средой почвенной вытяжки (таблица 1).

Общепринято, что почвы характеризуются пятью степенями обогащенности [22]. Согласно шкале обогащенности, исследуемая почва по численности бактерий относится к группе богатых почв.

По результатам метагеномного анализа, в микробиоме горизонтов доминируют филумы Actinobacteria (36-56\%) и Proteobacteria (31-43\%), в меньшей степени (ниже 5,0\%) присутствуют представители филумов Acidobacteria, Bacteroidetes, Chloroflexi, Firmicutes, Gemmatimonadetes, Verrucomicrobia u Planctomycetes (рисунок 3).

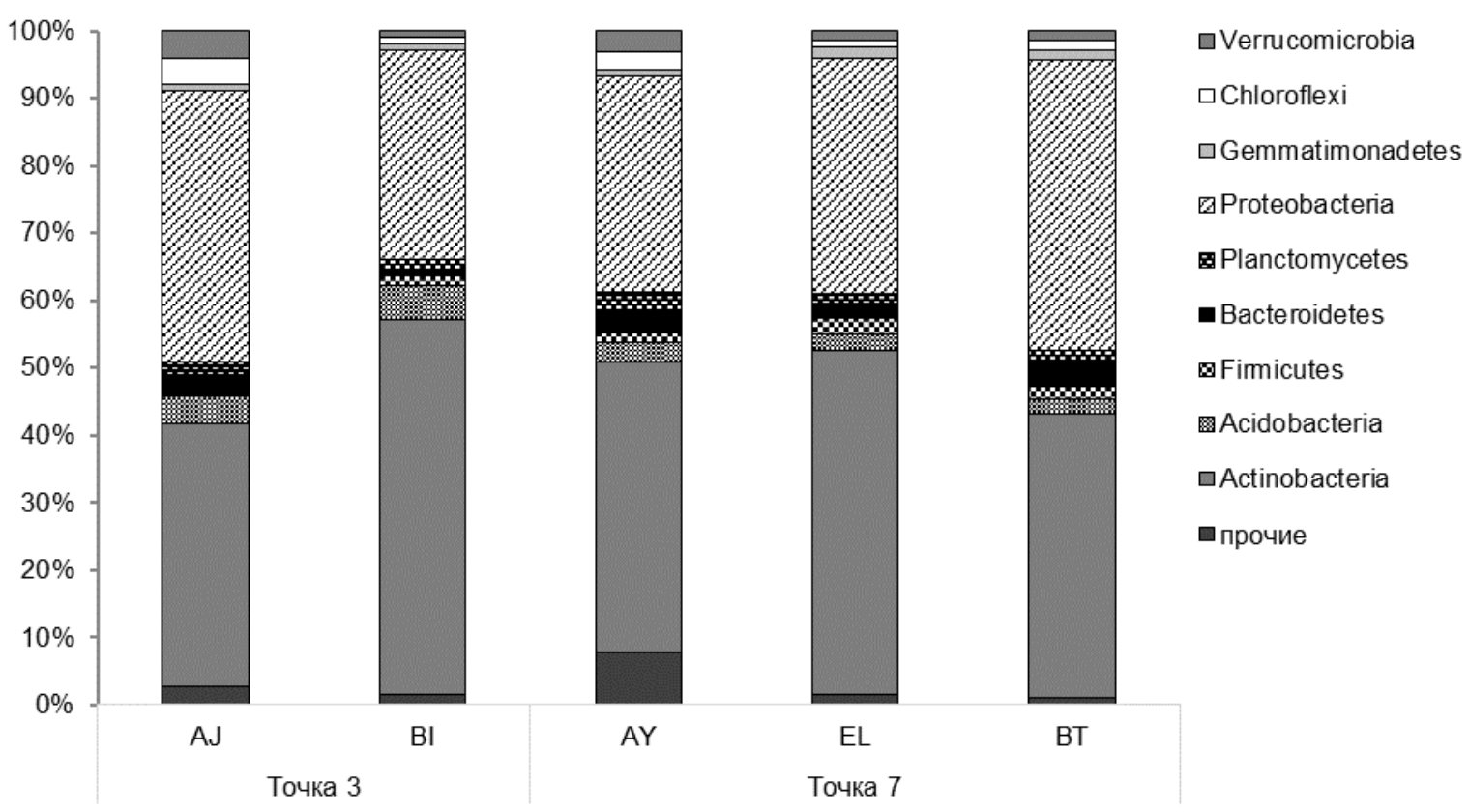

Рис. 3. Таксономическая структура бактериальных сообществ почвенных горизонтов.

Экологические особенности микробиома коррелируют с результатами агрохимического и микробиологического анализов и данными литературы. Так, в частности, присутствие 
ацидобактерий (рисунок 3) обусловлены пониженными значениями $\mathrm{pH}$ почвенной вытяжки (таблица 1), что также отмечено исследователями [23, 24]. Доминирование в структуре прокариот представителей фрилумов Actinobacteria и Proteobacteria (рисунок 3) подтверждено методом посева на питательные среды (таблицы 2, 3).

Таким образом, установлено, что почва поля относится к группе богатых почв, по содержанию актинобактерий - к почве с высоким уровнем супрессивности. Независимо от рельефра, численность актинобактерий в нижних горизонтах превышает численность в верхних слоях, а численность бацилл и других сапрофитных бактерий, напротив, понижается с увеличением глубины залегания почвенных слоев. Численность бактерий, использующих минеральные фрормы азота, и актинобактерий выше на равнинном ландшафрте, нежели на склоновом, свободных азотфиксаторов и аммонифрикаторов на склоновом. Совокупность полученных результатов подтверждает сопоставимость данных о структуре микробных сообществ почвенных горизонтов, полученных методами микробиологии и метагеномного анализа.

Работа выполнена в рамках программы повышения конкурентоспособности Казанского (Приволжского) фредерального университета среди ведущих мировых научнообразовательных центров.

\section{Литература}

1. De Santiago A., Recena R., Perea-Torres F., Moreno M. T., Carmona E., Delgado A. Relationship of soil fertility to biochemical properties under agricultural practices aimed at controlling land degradation // Land Degradation and Development. 2019. Vol. 30. P. 11211129.

2. Nicolopoulou-Stamati P., Maipas S., Kotampasi C., Stamatis P., Hens L. Chemical Pesticides and Human Health: The Urgent Need for a New Concept in Agriculture // Frontiers in Public Health. 2016. Vol. 4. P. 1-8.

3. Prashar P., Shah S. Impact of Fertilizers and Pesticides on Soil Microflora in Agriculture // Sustainable Agriculture Reviews. 2016. Vol. 19. P. 331-361.

4. Gattinger A., Jawtusch J., Muller A., Mäder P. No-till agriculture - a climate smart solution? // Bischöfliches Hilfswerk MISEREOR. 2011. Vol. 2. P. 1-24.

5. Добровольская Т. Г. Структура бактериальных сообществ почв / М.: Академкнига, 2002. 258 с.

6. Семенов М. В. Метабаркодинг и метагеномика в почвенно-экологических исследованиях: успехи, проблемы и возможности // Журнал общей биологии. 2019. Т. 80. С. 403-417.

7. Pookhao N., Sohn M. B., Li Q., Jenkins I., Du R., Jiang H., An L. A two-stage statistical procedure for feature selection and comparison in functional analysis of metagenomes // Bioinformatics. 2014. Vol. 31. P. 158-165.

8. Tyler H. L. Bacterial community composition under long-term reduced tillage and notill management // Journal of Applied Microbiology. 2019. Vol. 126. P. 1797-1807.

9. ГОСТ 17.4.4.02-2017. Охрана природы (ССОП). Почвы. Методы отбора и подготовки проб для химического, бактериологического, гельминтологического анализа. М.: Стандартинформ, 2018. 9 с. 
10. ГОСТ 28268-89. Почвы. Методы определения влажности, максимальной гигроскопической влажности и влажности устойчивого завядания растений. М.: Стандартинформ. 2006. 8 с.

11. ГОСТ 26483-85. Почвы. Приготовление солевой вытяжки и определение ее $\mathrm{pH}$ по методу ЦИНАО. М.: Изд-во стандартов, 1985. 6 с.

12. ГОСТ 26213-91. Почвы. Методы определения органического вещества. М.: Издво стандартов, 1992. 8 с.

13. ГОСТ Р 58596-2019. Методы определения общего азота. М.: Стандартинформ, 2018. 7 c.

14. ГОСТ 26204-91. Почвы. Определение подвижных соединений фоосфора и калия по методу Чирикова в модификации ЦИНАО. М.: Изд-во стандартов, 1992. 8 с.

15. Семина Н. А., Сидоренко С. В., Резван С. П., Грудинина С. А., Страчунский Л. С., Стецюк О. У., Козлов Р. С., Эйдельштейн М. В., Ведьмина Е. А., Столярова Л. Г., Власова И. В., Середа 3. С. Методические указания по определению чувствительности микроорганизмов к антибактериальным препаратам / М.: Федеральный центр госсанэпиднадзора Минздрава России, 2004. 92 с.

16. Казеев К. Ш., Даденко Е. В., Колесников С. И., Акименко Ю. В. Методы биодиагностики наземных экосистем / Ростов-на-Дону: ФГАОУВО ЮФУ, 2016. 357 с. ISBN 9785-9275-2214-9.

17. Garrity G.M., Brenner D.J., Krieg N.R., Staley J.T. Bergey's manual of systematic bacteriology. V. 2. New York: Springer., 2005. 2811 p. ISBN: 978-0-387-95040-2.

18. Vos P., Garrity G.M., Jones G., Krieg D., Ludwig N.R., Rainey W., Schleifer F.A., Whitman K.-H. Bergey's manual of systematic bacteriology. V. 3. New York: Springer., 2009. 1450 p. ISBN: 978-0-387-68489-5.

19. Whitman W., Goodfellow M., Kämpfer P., Busse H.-J., Trujillo M., Ludwig W., Suzuki K.-I., Parte A. Bergey's manual of systematic bacteriology. V. 5. New York: Springer., 2012. 2083 p. ISBN 978-0-387-68233-4.

20. Fatima F., Chaudhary I., Ali J., Rastogi S., Pathak N. Microbial DNA extraction from soil by different methods and its PCR amplification // Biochem. Cell. Arch. 2011. Vol. 11. P. 85-90.

21. Caporaso J. G., Kuczynski J., Stombaugh J., Bittinger K., Bushman F. D., Costello E. K., Fierer N., Peña A. G., Goodrich J. K., Gordon J. I., Huttley G. A., Kelley S. T., Knights D., Koenig J. E., Ley R. E., Lozupone C. A., McDonald D., Muegge B. D., Pirrung M., Reeder J., Sevinsky J. R., Turnbaugh P. J., Walters W. A., Widmann J., Yatsunenko T., Zaneveld J., Knight R. QIIME allows analysis of high-throughput community sequencing data // Nature Methods. 2010. Vol. 7. P. 335-336.

22. Звягинцев Д. Г. Биологическая активность почв и шкалы для оценки некоторых ее показателей // Почвоведение. 1978. № 6. С. 44-54.

23. Pajares S., Bohannan B. J. Ecology of Nitrogen Fixing, Nitrifying, and Denitrifying Microorganisms in Tropical Forest Soils // Frontiers in Microbiology. 2016. Vol. 7. P. 1-20.

24. Dai Z., Su W., Chen H., Barberán A., Zhao H., Yu M., Yu L., Brookes P. C., Schadt C. W., Chang S. X., Xu J. Long-term nitrogen fertilization decreases bacterial diversity and fa- 
vors the growth of Actinobacteria and Proteobacteria in agro-ecosystems across the globe // Global Change Biology. 2018. Vol. 24. P. 3452-3461.

Metagenomic analysis of the structure of prokaryotic communities of soil horizons at No-Till technology

Z. Yu. Siraeva*, E. A. Bulygina, R. K. Ismagilova, O. A. Kravzova

Kazan (Volga Region) Federal University

18 Kremlyovskaya Street, 420008 Kazan, Tatarstan Republic, Russia

*Email: zsiraeva@yandex.ru

For the first time in the Tatarstan Republic the structure of prokaryotic communities of soil horizons at No-Till technology was studied.

Keywords: No-Till technology, metagenomic analysis, microbiome, structure of the prokaryotic soil community. 